\title{
Management and population fluctuation of cassava mealybug Phenacoccus manihoti Matile-Ferrero (Hemiptera: Pseudococcidae)
}

\author{
Manejo e flutuação populacional da cochonilha da mandioca \\ Phenacoccus manihoti Matile-Ferrero (Hemiptera: Pseudococcidae)
}

\author{
Diego Gazola ${ }^{1 *}$; Vanda Pietrowski²; Claudemir Zucareli; \\ Diandro Ricardo Barilli'; ${ }^{4}$ Rudiney Ringenberg ${ }^{5}$
}

\begin{abstract}
:
Cassava is one of the main food species for low-income populations, playing a key role in the diet of several communities. In the Central-Southern region of Brazil, several pests are associated with cassava, among which the cassava mealybug stands out due to its high potential for damage. The aim of the present study was to evaluate the population dynamics and the effect of pruning and different cassava management on the developmental stages of mealybug, Phenacoccus. manihoti. The experiment was conducted in Santa Monica, PR, with 'Cauiá' cultivar, involving a randomized complete block design with four replications and six treatments: 1) No pruning: intact plants, 2) Pruning soil: pruned close to the soil without plant material, 3) Pruning at $15 \mathrm{~cm}$ : conventional pruning at $15 \mathrm{~cm}$ of the soil with vegetative material, 4) Pruning + branches: conventional pruning, with the middle portion of the plant in the plot and removal of the apical region of the plant, 5) Pruning + apical: conventional pruning, with the removal of the middle portion of the plant and retaining the apical parts of the plant, and 6) Pruning - branches - apical: conventional pruning, with the removal of the middle and apical portions of the plant. After 7-days of pruning, the number of eggs, nymphs, and adults were counted, and the population variation was monitored at weekly interval for a month. For the insect count, four sites were randomly chosen in a zigzag manner within each plot and four plants were evaluated, totaling 16 plants per plot. Based on the counts, the percentage of plants with eggs, nymphs, and adults was calculated. The data of the variables were transformed by $\sqrt{ }(x+0.5)$, subjected to analysis of variance and Scott Knot test (5\%). The percentage of plants with egg mass and adults of $P$. manihoti was highest in plots that had no pruning. The pruning close to the soil combined with the removal of vegetative material resulted in plants with fewest eggs of $P$. manihoti. Removal of the apical region portion of the cassava plant reduced the number of $P$. manihoti nymphs and adults.
\end{abstract}

Key words: Cultural management. Insect pest. Infestation. Manihot esculenta.

${ }^{1}$ Dr. em Agronomia, Universidade Estadual de Londrina, UEL, Londrina, PR, Brasil. E-mail: gazolad@gmail.com.

2 Prof ${ }^{a}$ Dr $^{\mathrm{a}}$, Departamento de Ciências Agrárias, Universidade Estadual do Oeste do Paraná, UNIOESTE, Campus Marechal Cândido Rondon, PR, Brasil. E-mail: vandapietrowski@gmail.com

3 Prof. Dr., Departamento de Ciências Agrárias da UEL, Londrina, PR, Brasil. E-mail: claudemircca@uel.br

4 Discente de Doutorado em Entomologia Agrícola, Universidade Estadual Paulista, UNESP, Jaboticabal, SP, Brasil. E-mail: diandro23@hotmail.com

5 Dr. Pesquisador, Embrapa Mandioca e Fruticultura, Centro Avançado Centro-Sul, Londrina, PR, Brasil. E-mail: rudiney. ringenberg@embrapa.br

* Author for correspondence 


\section{Resumo}

A mandioca é uma das principais espécies alimentícias para populações de baixa renda, desempenhando papel chave na dieta de diversas comunidades. No Brasil, várias pragas estão associadas a mandioca, dentre estas destaca-se a cochonilha da mandioca Phenacoccus manihoti devido ao seu alto potencial de dano. Assim, o objetivo deste estudo foi avaliar a flutuação populacional e o efeito da poda e de diferentes formas manejo da parte aérea da mandioca sobre as fases de desenvolvimento da cochonilha P. manihoti. O ensaio foi conduzido em Santa Mônica/PR, com a cultivar 'Cauiá' sob o delineamento de blocos ao acaso com quatro repetições e seis tratamentos: 1) Sem poda: plantas intactas, 2) Poda solo: poda rente ao solo sem material vegetal, 3) Poda a $15 \mathrm{~cm}$ : poda convencional a $15 \mathrm{~cm}$ do solo com material vegetal 4) Poda + ramas: poda convencional, com a parte mediana da planta na parcela e retirada da região apical da planta, 5) Poda + apical: poda convencional, com a retirada da parte mediada da planta e permanência da região apical da planta e 6) Poda - ramas - apical: poda convencional, com a retirada da parte mediada e apical da planta. Após 7 dias da realização da poda, houve a contagem do número de massas de ovos, ninfas e adultos, e a flutuação populacional foi avaliada a cada 7 dias, durante um mês. Para a contagem dos insetos, em cada parcela foram tomados quatro pontos ao acaso em zigue e zague, e nestes foram avaliadas quatro plantas, totalizando 16 plantas avaliadas por parcela. A partir dos dados da contagem obteve-se a porcentagem de plantas com massas de ovos, ninfas e adultos. Os dados das variáveis foram transformados por $\sqrt{ }(x+0.5)$, submetidos à análise de variância e ao teste de Scott Knot (5\%). A porcentagem de plantas com massa de ovos e adultos de P. manihoti foi maior sem a realização de poda na cultura. A poda rente ao solo com a retirada do material vegetativo resultou em plantas com menor massa de ovos de P. manihoti. Além disso, a retirada do terço superior da planta de mandioca diminuiu o número de ninfas e adultos de $P$. manihoti.

Palavras-chave: Inseto praga. Infestação. Manejo cultural. Manihot esculenta.

\section{Introduction}

Manihot esculenta Crantz cassava is cultivated in many of the Brazilian states, particularly in the North, followed by the Northeast and South. Inadequate crop management is a major limiting factor affecting productivity, which is estimated to be about $15.2 \mathrm{t} \mathrm{ha}^{-1}$ (SEAB, 2018).

Several pests are associated with cassava in Brazil. Among them, the mealybug Phenacoccus manihoti Matile-Ferrero (Hemiptera: Pseudococcidae) is a major pest attacking the shoots of the plant. The mealybug significantly affects the growth and the crop yield in the major producing regions of the world (PIETROWSKI et al., 2010; PARSA et al., 2012). This species was detected, and reportedly causes economic damage in cassava farms in the states of Paraná, São Paulo, Bahia, and Pernambuco (BELLOTTI et al., 2012).

Mealybugs are found on the underside of leaves and buds, both during their young and adult stages. The females develop a structure in the posterior part of the abdomen, known as the ovisac, in which the insects lay their eggs. These ovisacs are deposited on the underside of developed leaves or in the apical region of the plant (PIETROWSKI et al., 2010). Mealybugs directly damage the plant by sucking the sap and with the toxicity of their saliva, deforming the buds and, in bigger populations, by causing necrosis of apical tissues and consequently death of the apex. They can also cause an indirect damage by the growth of sooty mold on the leaf due to the release of honeydew. These damages mainly happen during the early budding of the second crop cycle, and is caused by mealybugs that migrate from the residual branches left in the soil after pruning (BELLOTTI et al., 1999, 2002; BENTO et al., 2002; PIETROWSKI et al., 2010).

As an alternative to the chemical pesticides commonly used in agriculture the managing of mealybugs can be accomplished through the use of resistant varieties, crop rotation and biological control (PIETROWSKI et al., 2010; BELLOTTI et al., 2012; GAZOLA, 2017). In addition, pruning 
and the subsequent management of the vegetative material of the plant can be a promising method for the management of mealybugs in the shoots of the plant. One of the main routes of dissemination of $P$. manihoti is the previously infested vegetative material (BELLOTTI et al., 1999; FARIAS, 2005).

Pruning is usually performed during the fall/ winter periods to facilitate crop treatments, such as the application of herbicides, collection of cuttings for new plantations and for increased yield. Additionally, pruning can also be used as a prophylactic measure in areas of high pest infestations and diseases (CONCEIÇÃO, 1987; FARIAS et al., 2006).

Pruning management may influence $P$. manihoti infestation and development in the field, since they preferentially feed on the phloem at the apex of cassava plants. When the shoots is removed, mainly the apical region, part of the insect population that feeds on stems or leaves is removed, leading to a population decrease or even elimination from the crop. Monitoring the fluctuation of the pest population in the field is also an important strategy to know the period of most infestation and its behavior vis-a-vis crop development. Knowledge of such information is valuable to develop an adequate control strategy. The aim of the present study was to evaluate the fluctuations in the insect population and the effect of pruning in cassava management to develop strategies to mitigate mealybug infestation.

\section{Material and Methods}

The experiment was conducted in a commercial agricultural area of cassava belonging to INDEMIL S/A company, located in Santa Mônica (23 ${ }^{\circ} 6^{\prime}$ $28^{\prime \prime}$ S $\left.53^{\circ} 6^{\prime} 32^{\prime \prime} \mathrm{W}\right)$, State of Paraná, Brazil, from August to September 2010. Cassava planting was mechanized and the fertilizer recommended for the soil in the region, which is derived from the Caiuá sandstone was provided. The soil in this region is of superficial sandy loam texture and has low organic matter content (SANTOS et al., 2013).
The Caiuá variety (popularly known as Olho Junto) of cassava was used in the experiments. This variety is commonly cultivated in Northwestern Paraná, mainly because of its high starch content. It is a late-maturity plant, preferably harvested after a 15-month cycle, yielding good quality starch and flour production. This is recommended for the sandy soils, mainly in the area covered by Caiuá sandstone (IAPAR, 2014). The plots were $10 \mathrm{~m}$ wide by 12 $\mathrm{m}$ long $\left(120 \mathrm{~m}^{2}\right)$, totaling an experimental area of $3,360 \mathrm{~m}^{2}$. The central area was considered useful for the plot, excluding two lateral lines on each side, with 190 plants per plot. Spacing was at $0.7 \mathrm{~m}$ between plants and $0.90 \mathrm{~m}$ between rows.

At the time of starting the experiments, the plants were about 10-months old and at the physiologically inactive stage. This facilitated pruning at the beginning of the second cycle. The experimental farm area had a history of mealybug incidences and the insects were observed in the plants as the experiments were initiated. The experiment was conducted in a randomized complete block design with four replications and six treatments: (1) no pruning: intact and unmanaged plants, (2) soil pruning: pruning close to soil removing the vegetative material from the plot, (3) pruning at 15 $\mathrm{cm}$ : conventional pruning (15 cm from soil) leaving the vegetative material in the plot, (4) pruning + branches: conventional pruning leaving the middle part of the plant in the field and removing the apical region; 5) pruning + apical region: conventional pruning removing the middle part of the plant from the field and leaving the apical region, (6) pruning - branches - apical region: conventional pruning removing the middle part and the apical region of the plant from the field.

The treatments (pruning) were performed on August 1, 2010 using a pruning knife. Budding occurred after five to seven days, and the area was weeded one month later. No chemicals were used for pests and disease control. The historical mean temperature for the region ranged from 19.4 and $21.1^{\circ} \mathrm{C}$ for the months of August and September, 
respectively. Rainfall data were measured using a rain gauge installed in the area. There were two rainy periods during the experiment. The first on August 10, with $10 \mathrm{~mm}$, and the second on August 25 , with $17 \mathrm{~mm}$ rainfall.

After pruning, the number of eggs, nymphs, and adults, as well as the population changes in mealybugs was monitored every week for one month. To count the number of insects, four sites were randomly chosen in a zigzag manner within each plot and four plants were evaluated, totaling 16 plants per plot. A different entry point was chosen in the plot at each evaluation. The percentage of plants with eggs, nymphs, and adults (presence or absence), and the mean number of nymphs and adults in the cassava plants were determined using the insect count data.

The data on the variables were transformed by $\sqrt{ }(x+0.5)$ and subjected to homogeneity and normality analysis of the residues using the ShapiroWilk test. Subsequently, the data were subjected to analysis of variance (ANOVA) and comparison of means using Scott Knot test (5\%) using the SISVAR statistical software.

\section{Results and Discussion}

There was a significant effect on the percentage of plants with $P$. manihoti egg masses, nymphs, and adults on the different types of pruning management evaluated for Caiuá cassava (Table 1). For the plants containing eggs (Table 2), we observed that the "no pruning", treatment had the highest mean percentage when crop was not managed, and the lowest percentage was seen in the treatment with "soil pruning", in which all the vegetative material was removed from the plot. The removal of all vegetative material from the plots decreased the spread of insects, while the "no pruning" treatment, in which the plant was left intact contained mealybugs throughout the crop cycle, and turning it into a major source of pest infestation.

Table 1. Variance analysis of the percentage of 'Caiuá' cassava plants with Phenacoccus manihoti eggs, nymphs, and adults in Santa Mônica, PR.

\begin{tabular}{lcccc}
\hline & DF & Eggs & Nymphs & Adults \\
\hline Treatment & 5 & $2022.92^{*}$ & $563.07^{*}$ & $1725.00^{*}$ \\
Block & 3 & 1054.05 & 1851.47 & 1313.02 \\
Error & 15 & 216.19 & 90.32 & 166.56 \\
\hline CV $(\%)$ & & 22.54 & 9.93 & 16.54 \\
\hline
\end{tabular}

* Significant at $5 \%$ probability using the Scott Knot test.

Table 2. Percentage of 'Caiuá' cassava plants with Phenacoccus manihoti eggs, nymphs, and adults by pruning type and management of the shoots of the plant in Santa Mônica, PR.

\begin{tabular}{lccc}
\hline Treatments & Eggs (\%) & Nymphs (\%) & Adults (\%) \\
\hline No pruning & $66.2500 \mathrm{a}^{*}$ & $73.1250 \mathrm{a}$ & $70.0000 \mathrm{a}$ \\
Pruning + apical region & $40.3125 \mathrm{~b}$ & $61.5625 \mathrm{a}$ & $49.3750 \mathrm{~b}$ \\
Pruning at $15 \mathrm{~cm}$ & $33.4375 \mathrm{~b}$ & $60.0000 \mathrm{a}$ & $40.9375 \mathrm{~b}$ \\
Pruning - branches - apical region & $26.5625 \mathrm{~b}$ & $52.8125 \mathrm{~b}$ & $32.1875 \mathrm{c}$ \\
Pruning + branches & $11.8750 \mathrm{c}$ & $39.0625 \mathrm{~b}$ & $13.4375 \mathrm{c}$ \\
Soil pruning & $2.5000 \mathrm{~d}$ & $47.8125 \mathrm{~b}$ & $19.0625 \mathrm{c}$ \\
\hline
\end{tabular}

* Same lowercase letters in the column do not differ from each other using the Scott Knot test at 5\% probability. 
For the percentage of Cauiá plants with $P$. manihoti nymphs, the treatments "no pruning," "pruning + apical region," and "pruning at $15 \mathrm{~cm}$ " had the highest mean values with no statistical differences between them. "Pruning - branches apical region," "pruning + branches," and "soil pruning" treatments had the lowest mean values. These results can be explained by the behavior of the nymphs, as during this phase, the mealybugs are very mobile, particularly during their first nymphal stage. Although the adults can also move, their movements seem to be restricted (PARSA et al., 2012). Thus, during the nymphal stage of $P$. manihoti, which lasts for approximately 17 days at $25 \pm 2{ }^{\circ} \mathrm{C}$ (BARILLI et al., 2014), there is intense insect migration, maximizing its dispersal in the plots in these treatments.

However, in plants with adult P. manihoti, the treatment "no pruning" had the highest mean number of insects and differed from the other treatments. As observed in the case of nymphs, the percentage of adults were the lowest in the "pruning - branches - apical region," "pruning + branches" and "soil pruning" treatments. The common characteristic among these treatments was the removal of the apical region of the plant from the plot. This part of the cassava plant has the highest incidence of $P$. manihoti. Thus, with the removal of this infestation focal point, low levels of re-infestation were observed in the plots after pruning.

These data corroborate with the results reported by Gazola (2017) in an experiment conducted in the municipalities of Diamante do Norte and Nova Londrina, also in the Northwestern Paraná. In evaluating the different types of pruning management for cassava crops, they reported that the greatest damage caused by $P$. manihoti mealybugs was in plants with no pruning in the two sampling sites, and also in other types of management where the vegetative material in the plot was retained. This data shows the potential for dissemination of these insects through infested vegetative material.
In general, removing the infested material from the area reduces the focus of insect infestation, and consequently decreases plant damage. Pruning management, where the apical part of the plant is removed delays mealybug re-infestation in cassava plants. This can be used as a control strategy, since delaying the movement of insects to the bud keeps the plants healthier to withstand pest attack until they are developed, resulting in minimal yield loss. Removing the apical region of plants infested with mealybugs is a common practice in some Asian countries with small areas of cassava cultivation. However, due to the large cultivated areas in Brazil, this manual strategy is unfeasible, given the high cost of labor, and requiring mechanized operations (GAZOLA, 2017).

According to Parsa etal. (2012), the dissemination of $P$. manihoti occurs mainly by anthropogenic mechanisms, such as the movement of stems/ cuttings contaminated during planting, where mealybugs survive by feeding on buds. Nymphs can also spread to nearby plants due to wind. In addition, the presence of mealybug disseminating insects should be considered in cassava pruning management. Chakupurakal et al. (1994) concluded that the occurrence of ants in cassava areas in Zambia increased with the population of $P$. manihoti. According to these authors, these insects can be associated with the dispersion of mealybugs in cassava plants.

The population variation of $P$. manihoti nymphs and adults during the period evaluated can be seen in Figure 1. Similarly, the number of nymphs and adults increased over time. The highest percentages were observed in the "no pruning" treatment, while the "soil pruning" and "pruning + branches" had the least mealybug counts.

Favorable growth conditions, as in the "no pruning" treatment, favors large-scale destruction by mealybugs, favored also by their high reproductive and dissemination capacity, and can damage up to $80 \%$ of the cassava plantation (BELLOTTI et al., 
1999; BENTO et al., 2002). According to Barilli et al. (2014), in an experiment conducted in a greenhouse with Santa Helena cassava cultivar (widely cultivated in Paraná), the life cycle of $P$. manihoti was completed in approximately 45 days, with more than $90 \%$ viable eggs and a fecundity rate of 240 eggs/female. According to these authors, the increase in insect population can exceed 200 individuals in each generation, resulting in significant damage to cassava crops.

Figure 1. Population fluctuation of Phenacoccus manihoti nymphs (A) and adults (B) with different management practices of the shoots of 'Caiuá' cassava during the 30-day period in Santa Mônica, PR.

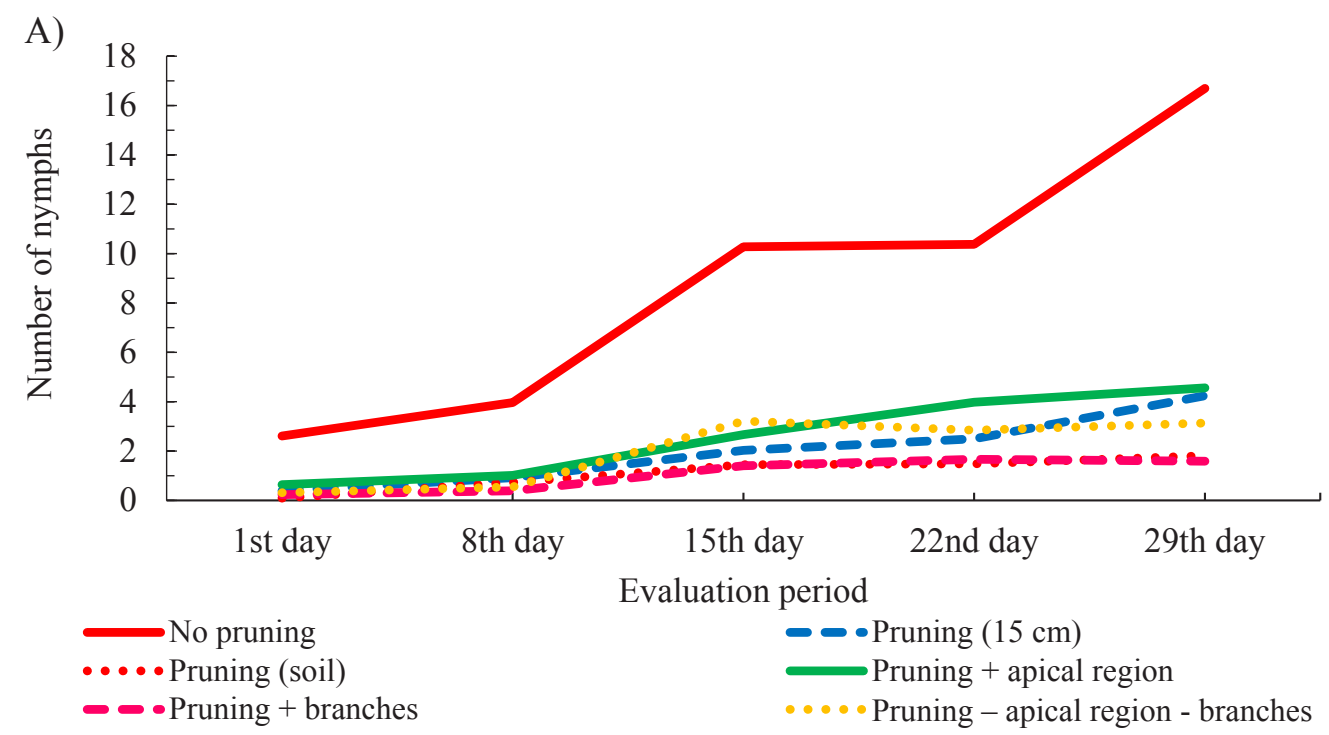

B)

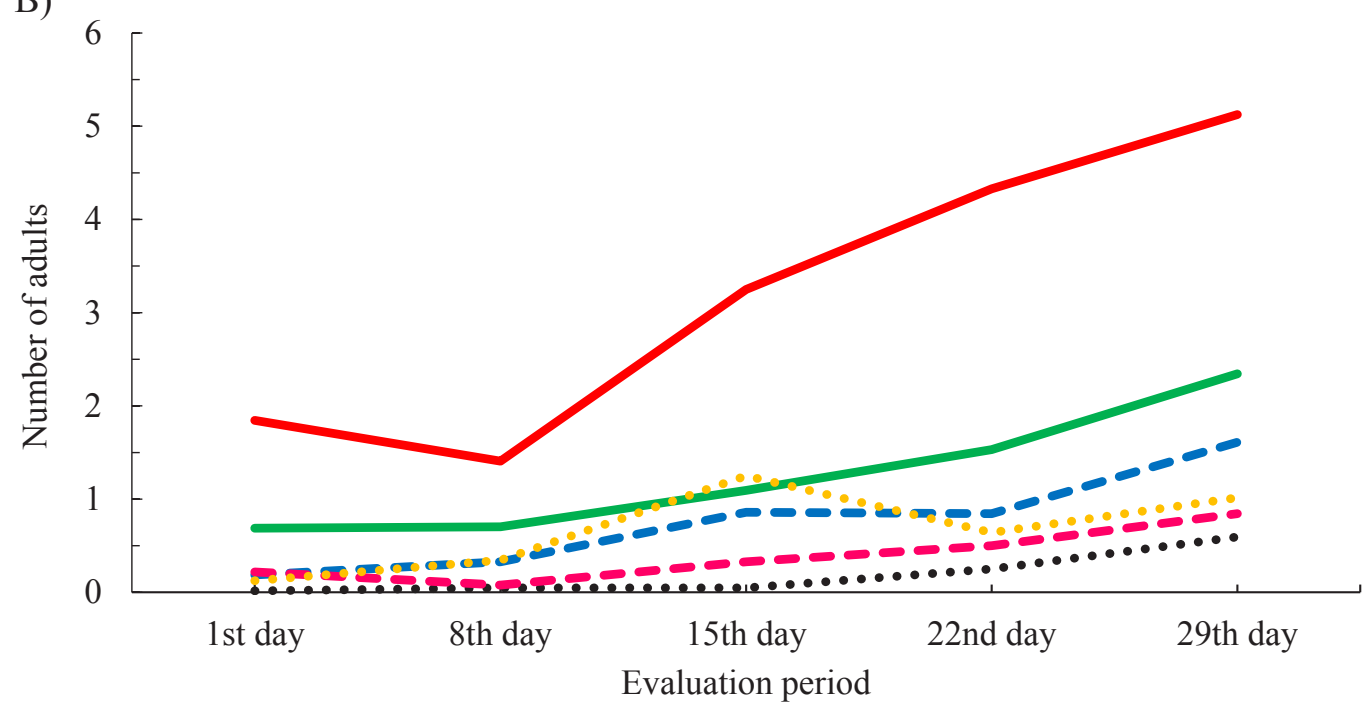

No pruning
-... Pruning (soil)
- Pruning + branches

$$
\begin{aligned}
& - \text { Pruning }(15 \mathrm{~cm}) \\
& \ldots . \text { Pruning }+ \text { apical region } \\
& \ldots \text { Pruning - apical region - branches }
\end{aligned}
$$

No pruning: intact plants, soil pruning: pruning close to the soil with no plant material in the field, pruning at $15 \mathrm{~cm}$ : conventional pruning $15 \mathrm{~cm}$ from the soil, with vegetal material in the field, pruning + branches: conventional pruning leaving the middle part of the plant in the field and removing the apical region, pruning + apical region: conventional pruning removing the middle part of the plant from the field and leaving the apical region, pruning - branches - apical region: conventional pruning removing the middle part and the apical region of the plant from the field. 
During the study period, the mean number of insects decreased. This can be explained by the climatic conditions in the region. P. manihoti mealybugs are known to be more detrimental to cassava crops during dry season and in higher temperature periods. Changes in rainfall patterns may have a substantial effect on the insect development (POLANÍA et al., 1999; BELLOTTI et al., 2012). During the study period, there were two periods of rainfall (between the $1^{\text {st }}$ and $2^{\text {nd }}$, and the $3^{\text {rd }}$ and $4^{\text {th }}$ evaluation periods) that may have reduced the insect survival in the plants and in the vegetative material left in the plots. According to Bellotti et al. (2012), insect population and plant damages are reduced at the beginning of the rainy period, giving some time for the crops to recover.

Little information is available on the biological characteristics of $P$. manihoti in Brazil, and more studies are necessary to obtain information about the cultivated cassava varieties and how they interact with mealybugs (BARILLI et al., 2014). Climate change forecasts indicate that certain agricultural areas will receive less rainfall in the future, thereby accelerating $P$. manihoti development and infestation in new areas (PARSA et al., 2012).

The scarcity of chemical and biological products to control insect pests associated with cassava is one of the main problems faced by farmers. Currently, there are no products registered to control $P$. manihoti in cassava (AGROFIT, 2018). Pest control is carried out without any technical assistance and most of the time using unregistered products (GAZOLA, 2017). Thus, the indiscriminate use of insecticides can select resistant insect populations to the active ingredients used in the formulations, besides amplifying the severity of damages caused by pests (SILVA et al., 2012).

The early detection of $P$. manihoti helps in preventing its spread and propagation in cassava. However, this detection period is short, as this insect can be rapidly dispersed. In Africa, for example, cassava mealybugs spread at a rate of $150 \mathrm{~km} / \mathrm{year}$, in contrast to other Hemiptera with less than $30 \mathrm{~km} /$ year. Similarly, in Thailand, P. manihoti is widely disseminated, causing yield losses of up to $50 \%$, which results in a loss of USD 30 million within two years after the first detection (FRISON; FELIU, 1991; LIEBHOLD; TOBIN, 2008; WINOTAI et al., 2010; BELLOTTI et al., 2012).

Using this approach, the removal of the shoots of cassava plants, mainly the apical region, can be considered an efficient and viable control strategy. It reduces the infestation focus of mealybugs in the field, although more detailed studies on the interaction of this strategy with local agroclimatic characteristics and cassava varieties are necessary. Also, the search for strategies to remove the apical region of the plant in areas of extensive monoculture are necessary to make this technique economically feasible for cassava farmers.

\section{Conclusion}

P. manihoti mealybugs were present throughout the study period, with a significant increase in unmanaged plants.

The percentage of plants with $P$. manihoti eggs and adults are higher when the plants are "no pruning".

"Soil pruning" with the removal of vegetative material results in plants with fewest $P$. manihoti eggs.

The removal of the apical region of the cassava plant reduces the number of $P$. manihoti nymphs and adults. This can be considered a strategy to manage this pest in the crop.

\section{Acknowledgments}

We thank Agrícola Nova Indemil (Santa Mônica/ PR unit) for the research area and for the technical and financial support of this experiment. 


\section{References}

BARILLI, R. D.; PIETROWSKI, V.; WENGRAT, A. P. G. DA S.; GAZOLA, D.; RINGENBERG, R. Biological characteristics of the cassava mealybug Phenacoccus manihoti (Hemiptera: Pseudococcidae). Revista Colombiana de Entomología, Bogotá, v. 40, n. 1, p. 2124, 2014.

BELlOTTI, A. C.; CAMPO, B. V. H.; HYMAN, G. Cassava production and pest management: present and potential threats in a changing environment. Tropical Plant Biology, Califórnia, v. 5, n.1, p. 39-72, 2012. DOI:10.1007/s12042-011-9091-4

BELlOTTI, A. C.; SMITH, L.; LAPOINTE, S. L. Recent advances in cassava pest management. Annual Review of Entomology, Palo Alto, v. 44, n. 1, p. 343-370, 1999. DOI: 10.1146/annurev.ento.44.1.343

BENTO, J. M. S.; MORAES, G. J.; MATOS, A. P.; WARUMBY, J. F.; BELLOTTI, A. C. Controle biológico da cochonilha no nordeste do Brasil. In: PARRA, J. R. P.; BOTELHO, P. S. M.; CORRÊA-PARRA B. S.; BENTO, J. M. S. (Ed.). Controle biológico no Brasil: parasitóides e predadores. São Paulo: Manole, 2002. p. 395-408.

CHAKUPURAKAL, J.; MARKHAM, R. H.; NEUENSCHWANDER, P.; SAKALA, M.; MALAMBO, C.; MULWANDA, D.; BANDA, E.; CHALABESA, A.; BIRD, T.; HAUG, T. Biological control of the Cassava Mealybug, Phenacoccus manihoti (Homoptera: Pseudococcidae), in Zambia. Biological Control, v. 4, n. 3, p. 254-262, 1994. DOI: 10.1006/bcon.1994.1032

CONCEIÇÃO, A. J. A mandioca. São Paulo: Nobel, $1987.382 \mathrm{p}$.

FARIAS, A. R. N. Pragas da mandioca: instruções práticas. Cruz das Almas: Embrapa Mandioca e Fruticultura, 2005. 32 p. (Circular técnica).

FARIAS, A.R.N.; BELlOTTI, A. C. Pragas e seu controle. In: SOUZA, L. da S.; FARIAS, A. R. N.; MATTOS, P. L. P.; FUKUDA, W. M. G. (Ed.). Aspectos socioeconômicos e agronômicos da mandioca. Cruz das Almas: Embrapa Mandioca e Fruticultura Tropical, 2006. p. 591-671.

FRISON, E. A.; FELIU, E. Technical guidelines for the safe movement of cassava germplasm. Rome: FAO/ IBPGR, 1991. $48 \mathrm{p}$.

GAZOLA, D. Práticas culturais e compostos secundários no manejo dacochonilha Phenacoccus manihoti MatileFerrero (Hemiptera: Pseudococcidae) em genótipos de mandioca. 2017. Tese (Doutorado em Agronomia) Universidade Estadual de Londrina, Londrina.
INSTITUTO AGRONÔMICO PARANAENSE IAPAR. Iapar registra cultivares de mandioca. Disponível em: $\quad$ http://www.iapar.br/modules/noticias/article. php?storyid=1569. 2014. Acesso em: 05 maio 2018 .

LIEBHOLD, A. M.; TOBIN, P. C. Population ecology of insect invasions and their management. Annual Review of Entomology, Palo Alto, v. 53, n. 1, p. 387-408, 2008. DOI: 10.1146/annurev.ento.52.110405.091401

PARSA, S.; TAKUMASA, K.; WINOTAI, A. The Cassava Mealybug (Phenacoccus manihoti) in Asia: first records, potential distribution, and an identification key. PLoS ONE, California, v. 7, n. 10, p. 10-15, 2012. DOI: 10.1371/journal.pone.0047675

PIETROWSKI,V.;RINGENBERG,R.;RHEINHEIMER, A. R.; BELLON, P. P.; GAZOLA, D.; MIRANDA, A. M. Insetos-praga na cultura da mandioca na região CentroSul do Brasil. Marechal Candido Rondon, 2010. 42 p.

POLANÍA, M. A.; CALATAYUD, P. A.; BELLOTTI, A. C. Comportamiento alimentício del piojo harinoso Phenacoccus herreni (Sternorrhyncha: Pseudococcidae) e influencia del déficit hídrico en plantas de yuca sobre su desarrollo. Revista Colombiana de Entomologia, Bogotá, v. 26, n. 1, p. 1-9, 1999.

SANTOS, H.G.; JACOMINE, P. K. T.; ANJOS, L. H. C.; OLIVEIRA, V. A.; LUMBRERAS, J. F.; COELHO, M. R.; ALMEIDA, J. A.; CUNHA T. J. F.; OLIVEIRA, J. B. Sistema brasileiro de classificação de solos. 3. ed. Brasília: Embrapa, 2013. 353 p.

SECRETARIA DE ESTADO AGRICULTURA E ABASTECIMENTO - SEAB. Prognóstico mandioca: safra 2017/18. Disponível em: http://www.agricultura. pr.gov.br/arquivos/File/deral/Prognosticos/2018 / Mandioca_2017_18.pdf. 2018. Acesso em: 05 maio 2018.

SILVA, A. S.; KASSAB, S. O.; GAONA, J. C. Insetospragas, produtos e métodos de controle utilizados na cultura de mandioca em Ivinhema, Mato Grosso do Sul. Revista Verde, Pombal, v. 7, n. 1, p. 19-23, 2012.

SISTEMA DE AGROTÓXICOS FITOSSANITÁRIOS - AGROFIT. Mandioca. Disponível em: http://agrofit. agricultura.gov.br/agrofit_cons/principal_agrofit_cons. 2018. Acesso em: 05 maio 2018.

WINOTAI, A.; G.; GOERGEN, M.; TAMÒ, M.; NEUENSCHWANDER, P. Cassava mealybug has reached Asia. Biocontrol News Information, v. 31, n. 1, p. 10-11, 2010. 